\title{
ANALISIS PENGARUH KURS, BI RATE DAN INFLASI TERHADAP IHSG DI BEI PERIODE 2014-2017
}

\author{
Esty Nidianti *) \\ Edi Wijayanto **)
}

\begin{abstract}
The aim of this study was to determine the effect of macro economic conditions which including the exchange rate, BI rate and inflation of the composite stock price index. The study had used quantitative approach. Determination of the sample was based on time series data periode January 2014 - December 2017 by using saturation sampling method, which resulted 48 as number of samples. This study also had chosen multiple linier regression as attempts to analyze data. The simultaneous test (F test) resulted that the exchange rate, BI rate, and inflation had given significant effect on the stock price index. Meanwhile, the partial test ( $t$ test) had indicated that the exchange rate variable and BI rate significantly influenced the stock price index. In contrast, rate of inflation had not showed significant effect on the stock price index.
\end{abstract}

Keywords : Exchange rate, BI rate, Inflation and The Composite Stock Price Index.

*) Mahasiswa Tugas Akhir Prodi Keuangan dan Perbankan, Jurusan Akuntansi, Politeknik Negeri Semarang

**) Dosen Jurusan Akuntansi, Politeknik Negeri Semarang

\section{PENDAHULUAN}

Pasar modal merupakan salah satu alternatif bagi investor untuk menginvestasikan uang yang dimiliknya untuk menghasilkan tingkat keuntungan yang optimal. Pasar modal juga mempunyai fungsi sarana alokasi dana yang produktif untuk memindahkan dana dari pemberi pinjaman ke peminjam (Jogiyanto, 2003 : 12). Setiap investor di pasar saham sangat membutuhkan informasi yang relevan dengan pengembangan transaksi di bursa, hal ini sangat penting untuk dijadikan bahan pertimbangan dalam menyusun strategi dan pengambilan keputusan investasi di pasar modal.

Pemodal atau investor hanya dapat memperkirakan berapa tingkat keutungan yang diharapkan (expected return) dan seberapa jauh kemungkinan hasil yang sebenarnya nanti akan menyimpang dari hasil yang diharapkan. Apabila kesempatan investasi mempunyai tingkat resiko yang lebih tinggi, maka investor akan mengisyaratkan tingkat keuntungan yang lebih tinggi pula (Jogiyanto, 2003). 
Pergerakan Indeks Harga Saham Gabungan (IHSG) mencerminkan kinerja pasar modal di Indonesia. Perubahan IHSG dikarenakan adanya perubahan harga dari seluruh saham yang tercatat di Bursa Efek Indonesia. Pergerakan IHSG tersebut dapat dipengaruhi oleh harga saham dimana harga saham dapat dipengaruhi oleh faktor internal maupun eksternal. Faktor eksternal adalah faktor makroekonomi yang merupakan pengaruh di luar perusahaan yang memiliki pengaruh terhdap kenaikan maupun penurunan kinerja perusahaan baik langsung maupun tidak langsung dan dapat mempengaruhi pergerakan IHSG seperti : tingkat inflasi, tingkat suku bunga, valuta asing, kondisi perekonomian internasional dan lain-lain (Samsul, 2006 : 200).

\section{KAJIAN TEORI}

\section{Pasar Modal}

Pasar modal menurut Undang-Undang Pasar Modal No. 8 Tahun 1995 tentang Pasar Modal mendefinisakan pasar modal sebagai kegiatan yang bersangkutan dengan penawaran umum dan perdagangan efek, perusahaan publik yang berkaitan dengan efek yang diterbitkannya, serta lembaga dan profesi yang berkaitan dengan efek. Terdapat tiga instrumen pasar modal, yaitu : saham, obligasi dan reksadana.

\section{Indeks Harga Saham Gabungan}

Indikator yang dapat menunjukkan pergerakan saham adalah indeks harga saham. Indeks Harga Saham Gabungan (IHSG) atau composite stock price index adalah suatu nilai yang digunakan untuk mengukur kinerja gabungan seluruh saham yang tercatat di suatu bursa efek (Sunariyah, 2011:140).

\section{Kurs}

Menguatnya kurs rupiah terhadap mata uang asing merupakan sinyal positif bagi perekonomian yang mengalami inflasi, hal ini dikarenakan menguatnya kurs rupiah terhadap mata uang asing akan menurunkan biaya impor bahan baku untuk produksi dan akan menurunkan tingkat suku bunga yang berlaku. Turunnya suku bunga akan mendorong investor untuk berinvestasi di saham (Tandelilin, $2001: 214$ ).

\section{BI Rate}

BI rate adalah suku bunga kebijakan yang mencerminkan sikap atau stance kebijakan moneter yang ditetapkan oleh Bank Indonesia dan diumumkan kepada publik. Suku bunga yang ditetapkan 
oleh Bank Indonesia adalah sebagai patokan bagi suku bunga pinjaman maupun simpanan bagi bank dan atau lembaga-lembaga keuangan di seluruh Indonesia. Suku bunga merupakan salah satu variabel yang dapat mempengaruhi harga saham karena perubahan tingkat suku bunga selanjutnya akan mempengaruhi keinginan seseorang untuk melakukan suatu investasi.

\section{Inflasi}

Inflasi adalah kecenderungan terjadinya peningkatan harga produk-produk secara keseluruhan (Tandelillin, 2017:345). Peningkatan inflasi secara relatif merupakan sinyal negatif bagi pemodal di pasar modal. Hal ini dikarenakan inflasi meningkatkan pendapatan dan biaya perusahaan. Jika biaya produksi lebih tinggi dari peningkatan harga yang dapat dinikmati oleh perushaan maka profitabilitas perusahaan akan menurun. Turunnya tingkat profitabilitas perusahaan akan mengurangi pendapatan riil yang diperoleh investor dari investasinya (Tandelilin, $2001: 214$ ).

\section{Hipotesis Penelitian}

$\mathrm{H}_{1}$ : variabel kurs berpengaruh signifikan terhadap IHSG.

$\mathrm{H}_{2}$ : variabel BI rate berpengaruh signifikan terhadap IHSG.

$\mathrm{H}_{3}$ : variabel inflasi berpengaruh signifikan terhadap IHSG.

\section{METODE}

\section{Desain Penelitian}

Penelitian ini menggunakan desain kuantitatif-kausal. Penelitian ini bertujuan untuk menjelaskan, menguji hubungan antar variabel, menemukan kasualitas dari variabel, menguji teori dan mencari generalisasi yang mempunyai nilai prediktif (untuk meramalkan suatu gejala) (Dharma, 2008 : 17).

\section{Metode Pengumpulan Data}

Metode pengumpulan data yang dilakukan dalam penelitian ini menggunakan studi kepustakaan dan dokumentasi. Data IHSG dapat diakses melalui website yahoo finance dan variabel independen seperti kurs, BI rate dan inflasi diakses melalui website Bank Indonesia. 


\section{Populasi}

Populasi adalah wilayah generalisasi yang terdiri atas objek atau subjek yang mempunyai kualitas dan karakteristik tertentu yang diterapkan oleh peneliti untuk dipelajari dan kemudian ditarik kesimpulannya (Sugiyono, 2012 : 80). Populasi pada penelitian ini adalah Indeks Harga Saham Gabungan (IHSG), kurs, BI rate dan inflasi.

\section{Teknik Sampling}

Sampel adalah sebagian anggota dari populasi yang dipilih dengan menggunakan prosedur tertentu sehingga diharapkan dapat mewakili populasinya (Sugiarto dkk, 2003:2). Teknik Sampling yang digunkan dalam penelitian ini adalah teknik sampling jenuh. Teknik sampling jenuh adalah teknik penentuan sampel bila semua anggota populasi digunakan sebagai sampel (Sugiyono, 2012 : 85).

\section{Identifikasi dan Definisi Operasional Variabel}

\section{Tabel 1}

Definisi Variabel Penelitian dan Pengukuran

\begin{tabular}{|l|l|c|c|}
\hline Variabel & \multicolumn{1}{|c|}{ Definisi Variabel } & Simbol & Satuan \\
\hline Kurs & $\begin{array}{l}\text { Harga satuan mata uang } \\
\text { dalam satuan mata uang lain. }\end{array}$ & $\mathrm{X}_{1}$ & $\begin{array}{c}\text { Kurs Tengah } \\
(\mathrm{Rp})\end{array}$ \\
\hline BI Rate & $\begin{array}{l}\text { Patokan bagi suku bunga } \\
\text { pinjaman maupun simpanan } \\
\text { bagi bank dan atau lembaga- } \\
\text { lembaga keuangan di } \\
\text { seluruh Indonesia. }\end{array}$ & $\mathrm{X}_{2}$ & $\begin{array}{c}\text { Persen } \\
(\%)\end{array}$ \\
\hline Inflasi & $\begin{array}{l}\text { Kecenderungan terjadinya } \\
\text { peningkatan harga produk- } \\
\text { produk secara keseluruhan }\end{array}$ & $\mathrm{X}_{3}$ & $\begin{array}{c}\text { Persen } \\
(\%)\end{array}$ \\
\hline IHSG & $\begin{array}{l}\text { Suatu nilai yang digunakan } \\
\text { untuk mengukur kinerja } \\
\text { gabungan seluruh saham } \\
\text { yang tercatat di suatu bursa } \\
\text { efek }\end{array}$ & $\mathrm{Y}$ & Level \\
\hline
\end{tabular}

Sumber : Data yang telah diolah (2018)

\section{Metode Analisis Data}

Metode analisis data pada penelitian ini adalah sebagai berikut : 


\section{Statistik Deskriptif}

Statsitik deskriptif merupakan statistik yang digunakan untuk menganalisa data dengan cara mendiskripsikan atau menggambarkan data yang telah terkumpul sebagai mana adanya tanpa bermaksud membuat kesimpulan yang berlaku untuk umum atau generalisasi (Sugiyono, 2011 : 169).

\section{Uji Asumsi Klasik}

\section{a. Uji Normalitas}

Uji Normalitas bertujuan untuk menguji apakah dalam model regresi, variabel pengganggu atau residual memiliki distribusi normal. Pada penelitian ini, untuk menguji normalitas sebuah model regresi menggunakan uji statistik non-parametik Kolmogorov - Smirnov (K-S).

\section{b. Uji Multikolinearitas}

Menurut Kuncoro (2011 :144) multikolinearitas pada dasarnya adalah adanya suatu hubungan linear yang sempurna (mendekati sempurna) antara beberapa atau semua variabel bebas. Menutut Ghozali (2014:34) mendeteksi ada tidaknya multikolinearitas dalam model regresi dapat dilihat dari nilai tolerance dan lawannya, VIF ( Variance Inflation Factor).

\section{c. Uji Heteroskedastisitas}

Menurut Hanke \& Reitsch (1998) uji heteroskedastisitas bertujuan untuk menguji apakah dalam model regresi terjadi ketidaksamaan varians dari residual suatu pengamatan ke pengamatan lain (Kuncoro, 2011 : 112). Menurut Ghozali (2014 : 46) model regresi yang baik adalah yang homoskedastisitas atau tidak terjadi heteroskedastisitas. Heteoskedastisitas dapat dilihat dengan menggunakan uji Glejser.

\section{d. Uji Autokorelasi}

Menurut Ghozali (2014 : 89) uji autokorelasi bertujuan untuk mengetahui apakah dalam suatu model regresi linier terdapat korelasi antara pengganggu pada periode t dengan kesalahan pada periode t-1 (sebelumnya). Alat analisis yang digunakan adalah uji Durbin - Watson (DW test). 


\section{Analisis Regresi Linier Berganda}

Regresi linier berganda digunkan untuk menguji pengaruh dua variabel atau lebih variabel independen (explanatory) terhadap satu variabel dependen dan umumnya dinyatakan dalam persamaan yang bertujuan untuk mengestimasi atau memprediksi nilai rata-rata variabel dependen berdasarkan nilai variabel independen (Ghozali, 2014 : 19). Persamaan regresi linier berganda tersebut adalah sebagai berikut (Ghozali, 2014 : 19) :

$\mathrm{Y}=\alpha+\beta 1 \mathrm{X} 1+\beta 2 \mathrm{X} 2+\beta 3 \mathrm{X} 3+\mu$

\section{Uji Kelayakan Model (Goodness of Fit)}

Menurut Ghozali (2014 : 20) uji kelayakan model digunakan untuk menguji ketepatan fungsi regresi sampel dalam menaksir nilai aktual. Secara statistik dapat diukur dari nilai koefisien determinasi, nilai statistik F dan nilai statistik t.

\section{a. Uji Statistik F (Uji Signifikasi Simultan)}

Uji statistik F pada dasarnya menunjukkan apakah semua variabel independen yang dimasukkan dalam model mempunyai pengaruh secara bersama-sama atau simultan terhadap variabel dependen (Ghozali, $2014: 22$ ).

\section{b. Uji Statistik t}

Uji statistik t pada dasarnya menunjukkan seberapa jauh pengaruh satu variabel penjelas atau independen secara individual dalam menerangkan variasi variabel dependen (Kuncoro, 2001 :97).

\section{c. Uji Koefisien Determinan $\left(\mathbf{R}^{2}\right)$}

Uji koefisien determinasi $\left(\mathrm{R}^{2}\right)$ merupakan uji kelayakan model yang digunakan untuk menguji seberapa besar kemampuan semua variabel independen yang digunkan dalam model regresi untuk menjelaskan variabel dependen (Kuncoro, $2001: 100$ ). 


\section{HASIL DAN PEMBAHASAN}

Model regresi linier berganda digunakan untuk mengetahui besarnya pengaruh variabel dependen kurs $\left(\mathrm{X}_{1}\right)$, BI rate $\left(\mathrm{X}_{2}\right)$ dan Inflasi $\left(\mathrm{X}_{3}\right)$ terhadap variabel independen yaitu IHSG $(\mathrm{Y})$. Persamaan hasil analisis regresi linier berganda pada penelitian ini dapat dilihat sebagai berikut :

$\mathrm{IHSG}=1751,145+0,483$ Kurs $-428,474 \mathrm{BIrate}-6,884 \operatorname{Inf}+\mu$

Berdasarkan hasil regresi linier berganda dapat dijabarkan sebagai berikut :

1. Konstanta 1751,145 menunjukkan bahwa kurs, BI rate dan inflasi dianggap tetap, maka nilai IHSG sebesar 1751,145.

2. Koefisien regresi kurs sebesar 0,483 menunjukkan bahwa setiap kenaikan kurs sebesar $1 \%$ dengan catatan variabel lainnya tetap, maka IHSG akan mengalami kenaikan sebesar 0,483.

3. Koefisien regresi BI rate sebesar $-428,474$ menunjukkan bahwa setiap penurunan BI rate sebesar $1 \%$ dengan catatan variabel lainnya tetap, maka IHSG akan mengalami penurunan sebesar 428,474 .

4. Koefisien regresi inflasi sebesar -6,884 menunjukkan bahwa setiap penurunan BI rate sebesar $1 \%$ dengan catatan jika variabel lainnya tetap, maka IHSG akan mengalami penurunan sebesar 6,884 .

\section{Tabel 2}

Uji F

ANOVA $^{\mathrm{a}}$

\begin{tabular}{|l|l|r|r|r|c|c|}
\hline \multicolumn{2}{|l|}{ Model } & Sum of Squares & \multicolumn{1}{|c|}{ Df } & Mean Square & F & \multicolumn{1}{c|}{ Sig. } \\
\hline \multirow{3}{*}{1} & Regression & 9959563,448 & 3 & 3319854,483 & 35,194 &, $000^{\mathrm{b}}$ \\
\cline { 2 - 8 } & Residual & 4150495,591 & 44 & 94329,445 & & \\
\cline { 2 - 8 } & Total & 14110059,040 & 47 & & & \\
\hline
\end{tabular}

a. Dependent Variable: IHSG

b. Predictors: (Constant), Inf, BIrate, Kurs

Sumber : Data sekunder telah diolah (2018)

Hasil uji $\mathrm{F}$ diatas juga menunjukkan bahwa tingkat signifikasinya sebesar $0,000<0,05$ yang menunjukkan bahwa pengaruh kurs, BI rate dan inflasi berpengaruh stimultan terhadap IHSG adalah signifikan. 
Tabel 3

Uji t

Coefficients $^{\mathrm{a}}$

\begin{tabular}{|c|c|c|c|c|c|c|}
\hline \multirow[b]{2}{*}{ Mode } & & \multicolumn{2}{|c|}{$\begin{array}{l}\text { Unstandardized } \\
\text { Coefficients }\end{array}$} & \multirow{2}{*}{\begin{tabular}{|c|}
$\begin{array}{l}\text { Standardized } \\
\text { Coefficients }\end{array}$ \\
Beta \\
\end{tabular}} & \multirow[b]{2}{*}{$\mathrm{t}$} & \multirow[b]{2}{*}{ Sig. } \\
\hline & & B & Std. Error & & & \\
\hline 1 & (Constant) & 1751,145 & 856,414 & & 2,045 &, 047 \\
\hline \multirow[t]{3}{*}{1} & Kurs &, 483 &, 064 &, 660 & 7,536 &, 000 \\
\hline & BIrate & $-428,474$ & 51,423 &,- 708 & $-8,332$ &, 000 \\
\hline & Inf & $-6,884$ & 27,457 &,- 021 &,- 251 & ,803 \\
\hline
\end{tabular}

a. Dependent Variable: IHSG

Sumber : Data sekunder telah diolah (2018)

Berdasarkan Tabel 3 Uji t di atas maka, hasil dapat dijelaskan sebagai berikut :

1. Kurs terhadap Indeks Harga Saham Gabungan (IHSG)

Hasil pengolahan data pada Tabel 3 menunjukkan bahwa signifikasinya dibawah 0,05 yaitu 0,00. Hal ini menunjukkan bahwa pengaruh kurs terhadap IHSG adalah signifikan. dan menunjukkan bahwa kenaikan kurs rupiah terhadap USD akan menyebabkan kenaikan pada IHSG, begitu pula sebaliknya.

Kurs rupiah yang mengalami penguatan menunjukkan keadaan perekonomian yang baik sehingga menyebabkan banyak investor yang berinvestasi dan mengakibatkan harga saham mengalami kenaikan. Selain itu menguatnya kurs rupiah terhadap mata uang asing dapat menurunkan biaya impor bahan baku untuk produksi dan dapat meningkatkan laba perusahaan sehingga investor menginvestasikan dana yang dimilikinya pada perusahaan sehingga harga saham perusahaan tersebut akan meningkat dan menyebabkan IHSG meningkat.

\section{BI rate terhadap Indeks Harga Saham Gabungan (IHSG)}

Hasil pengolahan data pada Tabel 3 menunjukkan bahwa signifikasinya dibawah 0,05 yaitu 0,00. Hal ini menunjukkan bahwa pengaruh BI rate terhadap IHSG adalah signifikan dan menunjukka bahwa apabila BI rate mengalami peningkatan maka indeks harga saham mengalami penurunan.

Apabila BI rate mengalami peningkatan, maka indeks harga saham akan mengalami penurunan. BI rate akan mempengaruhi tingkat bunga dan deposito. Apabila tingkat suku bunga tinggi maka investor akan lebih berminat untuk menanamkan modal yang dimilikinya dalam bentuk tabungan atau deposito. 
3. Inflasi terhadap Indeks Harga Saham Gabungan (IHSG)

Hasil pengolahan data pada Tabel 3 menunjukkan bahwa diatas 0,05 yaitu 0,83. Hal ini menunjukkan bahwa pengaruh inflasi terhadap IHSG adalah tidak signifikan dan menunjukkan bahwa inflasi tidak memiliki pengaruh banyak terhadap keputusan investor untuk menanamkan modalnya.

Hal ini menandakan bahwa tingkat inflasi tidak berpengaruh banyak terhadap keputusan investor dalam menanamkan modalnya tetapi mempengaruhi laju indeks harga saham. Kebijakan moneter Bank Indonesia berpengaruh dalam memulihkan kepercayaan pasar, dimana walaupun terjadi inflasi seorang investor lebih memilih untuk mempertahankan saham yang dimilikinya daripada menjual saham saat terjadi inflasi naik.

\section{Tabel 4}

\section{Uji Koefisien Determinasi $\left(\mathbf{R}^{2}\right)$ Model Summary}

\begin{tabular}{|c|c|c|c|c|c|}
\hline Model & $\mathrm{R}$ & R Square & $\begin{array}{l}\text { Adjusted R } \\
\text { Square }\end{array}$ & $\begin{array}{l}\text { Std. Error of the } \\
\text { Estimate }\end{array}$ & Durbin-Watson \\
\hline 1 &, $840^{a}$ & ,706 & ,686 & 307,13099 & ,649 \\
\hline
\end{tabular}

Sumber : Data sekunder telah diolah (2018)

Berdasarkan Tabel 4 dapat diketahui bahwa koefisien determinasi (Adjusted $R$ square) sebesar $0,686(68,6 \%)$ yang artinya bahwa variasi variabel independen yang digunakan pada penelitian ini yaitu, kurs, BI rate dan inflasi mampu menjelaskan sebesar 68,6\% variasi variabel IHSG. Sisanya sebesar 31,4\% (100\%-68,8\%) dipengaruhi oleh variasi variabel lain yang tidak termasuk dalam model penelitian ini.

\section{KESIMPULAN DAN SARAN}

\section{Kesimpulan}

Kesimpulan dari penelitian ini berdasarkan analisis dan pembahasan yang telah dilakukan yaitu, sebagai berikut :

1. Kurs berpengaruh signifikan terhadap IHSG

2. BI rate berpengaruh signifikan terhadap IHSG

3. Inflasi berpengaruh tidak signifikan terhadap IHSG 


\section{Saran}

Berdasarkan kesimpulan penelitian yang telah dijabarkan, maka saran yang dapat diberikan adalah:

1. Perusahaan sebaiknya lebih memperhatikan informasi seperti kurs, BI rate dan inflasi yang dapat mempengaruhi kinerja perusahaan dan berdampak pada pendapatan perusahaan sehingga diperlukan analisis khusus untuk memantau kondisi yang ada agar tidak mengalami kerugian, dengan memiliki analisis khusus perusahaan dapat meningkatkan profitabilitas dan memperkuat fundamental perusahaan. Perusahaan yang memiliki fundamental yang baik akan menarik investor untuk menanamkan modalnya pada perusahaan tersebut dan akan menaikkan indeks harga saham.

2. Investor perlu menimbangkan tingkat inflasi yang terjadi, apabila inflasi sedang naik investor tidak perlu gegabah untuk menjual sahamnya. Inflasi yang sedang naik akan menimbulkan kerugian yang lebih besar apabila menjualnya, daripada mempertahankan saham tersebut. Inflasi yang naik kurang dari 10\% pertahun tidak akan bertahan lama hingga kebijakan pemerintah mengembalikan kepercayaan pasar.

3. Pemerintah dapat melaksanakan kebijakan moneter dalam rangka mencapai stabilitas harga, dengan memberi pertimbangan yang lebih pada harga aset (finansial dan properti) sehingga kebijakan pemerintah dapat menstabilkan perekonomian dengan menaikkan suku bunga BI atau menurunkan suku bunga BI dengan demikian, inflasi dapat diperkirakan berada di bawah sasaran yang telah ditetapkan.

Apabila kebijakan tersebut dapat menstabilkan perekonomian maka, nila tukar rupiah terhadap mata uang asing dapat menguat dan membuat kepercayaan pasar meningkat sehingga IHSG juga dapat meningkat.

\section{DAFTAR PUSTAKA}

Amin,Muhammad Zuhdi. 2012. "Pengaruh Tingkat Inflasi, Suku Bunga SBI, Nilai Kurs Dollar (USD/IDR), dan Indeks Dow Jones (DJIA) Terhadap Pergerakan Indeks Harga Saham 
Gabungan Di Bursa Efek Indonesia (BEI) (Periode 2008-2011)’.Jurnal Skripsi. Universitas Brawijaya

Asdo,Dicky. 2014. Analisis Pengaruh Kurs, Inflasi, BI Rate dan Volume Perdagangan Saham Terhadap IHSG Periode 2008 - 2013.Tugas Akhir. Politeknik Negeri Semarang

Aziz, Musdalifah, dkk. 2015. Manajemen Investasi Fundamental, Teknikal, Perilaku Investor dan Return Saham. Yogyakarta : Deepublish

Bank Indonesia.2017.BI Rate. www.bi.go.id/id/moneter/bi-rate/data (24 Januari 2018)

Bank Indonesia.2017.Inflasi. www.bi.go.id/id/moneter/inflasi/data (24 Januari 2018)

Bank Indonesia. 2017 . Kurs. www.bi.go.id/id/moneter/informasi-kurs/transaksi-bi (24 Januari 2018)

Bursa Efek Indonesia.Buku Panduan Indeks Harga Saham Bursa Efek Indonesia. 2010. Jakarta : BEI

Dharma, Surya. 2008. Pendekatan, Jenis dan Metodologi Penelitian Pendidikan. Departemen Pendidikan Nasional

Ekananda, Mahyus.2014.Ekonomi Internasional.Jakarta : Erlangga

Ernayani, Rihfenti dan Mursalin, Adi.2015. "Pengaruh Kurs Dollar, Indeks Dow Jones dan Tingkat Suku Bunga SBI terhadap IHSG (periode Januari 2005- Januari 2015)”.SNEMA Fakultas Ekonomi Universitas Negeri Padang.ISBN : 978-602-17129-5-5

Ghozali, Imam. 2014. Ekonometrika : Teori, Konsep dan Aplikasi dengan IBM SPSS. Semarang : Universitas Diponegoro

Jogiyanto, H.M. 2003. Teori Portofolio dan Analisis Investasi Edisi Kedua. Yogyakarta : BPFE

Jonathan, Sarwono. 2006. Metode Penelitian Kuantitatif dan Kualitatif. Yogyakarta : Graha Ilmu

Kewal,Surmaya Suci.2012. "Pengaruh Inflasi, Suku Bunga, Kurs dan Pertumbuhan PDB terhadap Indeks Harga Saham Gabungan”.Jurnal Economia.Volume 8. Nomor 1 
Kumalasari, Hidayat dan Azizah, Devi.2016. "Pengaruh Nilai Tujar, BI Rate, Tingkat Inflasi dan Pertumbuhan Ekonomi Terhadap Indeks Harga Saham Gabungan (Studi Pada Indeks Harga Saham Gabungan di BEI periode Juli 2005-Juni 2015)’.Jurnal Administrasi Bisnis (JAB) Vo.34 No 1

Kuncoro, Mudrajad. 2001. Metode Kuantitatif Edisi 3. Yogyakarta : UPP AMP YKPN

Liauw, Joven Sugianto dan Wijaya, Trisnadi.2013. “Analisis Pengaruh Tingkat Inflasi, Tingkat Suku Bunga SBI dan Nilai Tukar Rupiah terhadap Indeks Harga Saham Gabungan (IHSG) di Bursa Efek Indonesia”.STIE MDP

Nasution, S. 2011. Metode Research (Penelitian Ilmiah). Jakarta : Bumi Aksara

Nazir, Moh. 2011. Metode Penelitian. Aceh : Ghalia Indonesia

Nofiatin,Ike.2013. "Hubungan Inflasi, Suku Bunga, Produk Domestik Bruto, Nilai Tukar, Jumlah Uang Beredar, dan Indeks Harga Saham Gabungan (IHSG) Periode 2005-2011'.Jurnal Aplikasi Manajemen.Volume 11 No 2

Paradita, Paramita.2017. Analisis Pengaruh Inflasi, Suku Bunga BI, Nilai Tukar Rupiah dan PDB Terhadap IHSG periode 2012-2016. Skripsi. Politeknik Negeri Semarang

Sahamok.2017.Jumlah perusahaan di BEI. www.sahamok.com (29 Januari 2018)

Samsul, Mohammad.2006.Pasar Modal dan Manajemen Portofolio.Jakarta : Erlangga

Simorangkir, Suseno.2014.Sistem dan Kebijakan Nilai Tukar.Jakarta: PPSK

Sugiarto,dkk.2003. Teknik Sampling. Jakarta : Gramedia Pustaka Utama

Sugiyono. 2007. Metode Penelitian Kuantitatif, Kualitatif dan R\& D. Bandung. Alfabeta

Suhartono dan Qudsi, Fadillah.2009. Portofolio Investasi dan Bursa Efek Pendekatan Teori dan Praktik.Yogyakarta: YKPN 
Sunardi dan Ula,Laila.2017. "Pengaruh BI Rate,Inflasi dan Kurs Terhadap Indeks Harga Saham Gabungan (IHSG)'.Jurnal Sekuritas (Saham Ekonomi Keuangan dan Investasi) Vol. 1 No.2 Prodi Manajemen Universitas Pamulang

Sunariyah.2011. Pengantar Pengetahuan Pasar Modal. Edisi Keenam. Yogyakarta : (UUP) STIM YKPN

Tandelilin, Eduardus. 2001. Analisis Investasi dan Manajemen Portofolio. Yogyakarta:BPFE

Thobarry,Achmad Ath.2009. Analisis Pengaruh Nilai Tukar, Suku Bunga, Laju Inflasi, dan Pertumbuhan GDP Terhadap Indeks Harga Saham Sektor Property (Kajian Empiris pada Bursa Efek Indonesia Periode Pengamatan 2000-2008).Tesis. Program Studi Magister Manajemen Program Pasca Sarjana Universitas Diponegoro

Undang-Undang Nomor 8 Tahun 1995. Tentang Pasar Modal

Utari, Diah G.A, Cristina, S.D, dan Pambudi,S.2015. Inflasi di Indonesia : Karakteristik dan Pengendaliannya .Jakarta : BI Institute

Wijaya, Tantra.2015. "Faktor-Faktor yang Mempengaruhi Nilai IHSG yang Terdaftar di Bursa Efek Indonesia”.Jurnal Ilmu dan Riset Manajemen Vol.4 No.6.

Yahoo finance.2017.IHSG. https://finance.yahoo.com (24 Januari 2018) 